\title{
Genetic Diversity of Eight Domestic Goat Populations Raised in Turkey
}

\author{
Zafer Bulut, ${ }^{1}$ Ercan Kurar, ${ }^{2}$ Yusuf Ozsensoy, ${ }^{3}$ \\ Vahdettin Altunok, ${ }^{1}$ and Mehmet Nizamlioglu ${ }^{1}$ \\ ${ }^{1}$ Faculty of Veterinary Medicine, Department of Biochemistry, Selcuk University, 42031 Konya, Turkey \\ ${ }^{2}$ Meram Faculty of Medicine, Department of Medical Biology, Necmettin Erbakan University, 42080 Konya, Turkey \\ ${ }^{3}$ Faculty of Veterinary Medicine, Department of Biometrics and Genetics, Cumhuriyet University, 58140 Sivas, Turkey \\ Correspondence should be addressed to Zafer Bulut; zbulut@selcuk.edu.tr
}

Received 13 January 2016; Revised 10 March 2016; Accepted 13 March 2016

Academic Editor: Giuseppe Piccione

Copyright (C) 2016 Zafer Bulut et al. This is an open access article distributed under the Creative Commons Attribution License, which permits unrestricted use, distribution, and reproduction in any medium, provided the original work is properly cited.

\begin{abstract}
The objective of this study was to determine the intra- and intergenetic diversities of eight different goat populations in Turkey including Hair, Angora, Kilis, Yayladag, Shami, Honamli, Saanen, and Alpine. A total of 244 DNA samples were genotyped using 11 microsatellites loci. The genetic differentiation between breeds was considerable as a result of the statistically significant $(P<$ $0.001)$ pairwise $F_{\mathrm{ST}}$ values of each pair of breeds. Exceptionally, $F_{\mathrm{ST}}$ values calculated for Honamli and Hair breeds were statistically nonsignificant $(P>0.05)$. Heterozygosity values ranged between 0.62 and 0.73 . According to the structure and assignment test, Angora and Yayladag goats were assigned to the breed they belong to, while other breeds were assigned to two or more different groups. Because this study for the first time presented genetic data on the Yayladag goat, results of structure analysis and assigned test suggest that further analyses are needed using additional and different molecular markers.
\end{abstract}

\section{Introduction}

While goat breeding has decreased between 1991 and 2009, the number of Hair goats continuously and significantly increased between 2009 and 2014 in Turkey. Among goat populations, Hair goat is the predominant (98\%) type raised in Turkey [1]. Although Hair goat is most widely reared in the Mediterranean, Aegean, and Southeastern Anatolian regions, it is considered the most common native breed raised nationwide. Angora goat is raised in the Central Anatolia region, primarily in Ankara, as well as in a few provinces of the Southeastern Anatolia and Eastern Anatolia regions [2]. Kilis goat is distributed in the Southeastern Anatolia region, primarily in Gaziantep, Kilis, and Hatay provinces. Honamli goat is reared in the Mediterranean region, in the foothills of the Taurus Mountains, primarily in Konya, Isparta, and Antalya provinces [2]. Compared to other populations, Saanen, Alpine, Shami, and Yayladag goats are rarer in Turkey; however, other goat populations, except for Hair and Tiftik goats, have not been included in TUIK data [1]. In Turkey, there were no data or information particularly about the population reported as Yayladag goat in the present study. Yayladag and Shami goats are raised in the southern part of Turkey, mainly in Hatay Province and close to the Syrian border. Phenotypic, population, and geographical properties of these breeds were described in detail elsewhere $[3,4]$.

The earliest phylogenetic analysis of goat populations in Turkey comprises protein and enzyme polymorphism [5-7]. However, microsatellite markers are widely used in genetic characterization studies. The genetic relation between different goat populations was investigated using microsatellite markers in various countries [8-11]. It was reported that microsatellites had been most frequently used in genetic characterization studies conducted in Asian and African countries [12]. In Turkey, genetic diversity studies with microsatellites had been conducted in goat [13], cattle [14, 15], and horse [16] populations.

Determination of genetic structure and genetic characterization of animals is the first step in developing gene sources protection strategies. Therefore, the present study aimed to 
TABLE 1: Microsatellites used in the study.

\begin{tabular}{lcllc}
\hline Locus & Chromosome & \multicolumn{2}{c}{ Primer sequence } & Allele range $(\mathrm{bp})$ \\
\hline MAF70 & & Forward $\left(5^{\prime} \rightarrow 3^{\prime}\right)$ & Reverse $\left(5^{\prime} \rightarrow 3^{\prime}\right)$ & $134-168$ \\
INRA023 & 4 & cacggagtcacaaagagtcagacc & gcaggactctacggggcctttgc & $196-215$ \\
SPS113 & 3 & gagtagagctacaagataaacttc & taactacagggtgttagatgaact & $134-158$ \\
CSRD247 & 10 & cctccacacaggcttctctgactt & cctaacttgcttgagttattgccc & $220-247$ \\
McM527 & 14 & ggacttgccagaactctgcaat & cactgtggtttgtattagtcagg & $165-187$ \\
ILSTS087 & 5 & gtccattgcctcaaatcaattc & aaaccacttgactactccccaa & $135-155$ \\
BM6444 & 28 & agcagacatgatgactcagc & ctgcctcttttcttgagag & $118-200$ \\
P19 (DYA) & 2 & ctctgggtacaacactgagtcc & tagagagtttcctgtccatcc & $160-196$ \\
TCRVB6 & 20 & aacaccatcaaacagtaagag & catagtaacagatcttcctaca & $217-255$ \\
DRBP1 & Unknown & gagtctcagcaagcaggtc & ccaggaattggatcacacct & $195-229$ \\
ETH10 & 23 & atggtgcagcagcaaggtgagca & gggactcagtctctctatctctttg & $200-210$ \\
\hline
\end{tabular}

TABLE 2: Microsatellite markers and observed number of alleles.

\begin{tabular}{|c|c|c|c|c|c|c|c|c|c|}
\hline \multirow{2}{*}{ Loci } & \multicolumn{9}{|c|}{ Population } \\
\hline & Kilis & Yayladag & Shami & Honamli & Saanen & Hair & Angora & Alpine & Total \\
\hline SPS113 & 7 & 6 & 6 & 7 & 9 & 7 & 10 & 5 & 11 \\
\hline McM527 & 8 & 5 & 6 & 7 & 6 & 7 & 6 & 6 & 10 \\
\hline CSRD247 & 10 & 7 & 9 & 8 & 6 & 8 & 9 & 8 & 11 \\
\hline BM6444 & 16 & 13 & 18 & 17 & 15 & 20 & 25 & 10 & 33 \\
\hline ILSTS087 & 7 & 5 & 6 & 8 & 7 & 9 & 8 & 6 & 10 \\
\hline TCRVB6 & 12 & 10 & 9 & 11 & 9 & 11 & 12 & 8 & 14 \\
\hline DRBP1 & 6 & 8 & 6 & 6 & 4 & 6 & 8 & 4 & 14 \\
\hline MAF70 & 7 & 11 & 11 & 9 & 9 & 11 & 9 & 7 & 18 \\
\hline ETH10 & 4 & 6 & 5 & 5 & 4 & 6 & 8 & 4 & 14 \\
\hline P19 (DYA) & 8 & 7 & 11 & 10 & 10 & 9 & 8 & 7 & 13 \\
\hline INRA023 & 8 & 8 & 9 & 6 & 4 & 6 & 8 & 5 & 12 \\
\hline Mean & 8.45 & 7.82 & 8.73 & 8.55 & 7.55 & 9.09 & 10.09 & 6.36 & 14.55 \\
\hline
\end{tabular}

investigate genetic diversity among some goat populations in Turkey using microsatellite markers. Also, this study is the first report regarding Yayladag goat population.

\section{Materials and Methods}

2.1. Samples. In the present study, a total of 244 blood samples, which were obtained from Kilis $(n=32)$, Yayladag $(n=32)$, Shami $(n=32)$, Honamli $(n=32)$, Saanen $(n=28)$, Hair $(n=32)$, Angora $(n=43)$, and Alpine $(n=13)$ goat populations, were drawn into tubes containing $\mathrm{K}_{3}$-EDTA. DNA isolation was performed using standard phenol/chloroform method [17]. The study was approved by Selcuk University, Veterinary Faculty, Experimental Animal Research Ethical Committee (decision number: 2015/69).

2.2. Methods. Genomic DNAs were amplified by Polymerase Chain Reaction (PCR) using 11 microsatellite markers (Table 1), which were selected from the list recommended by the United Nations Food and Agriculture Organization (FAO) and International Society of Animal Genetics (ISAG). As per the PCR protocol, $1 \mathrm{x} \mathrm{Mg}^{++}$free PCR buffer (Fermentas), $200 \mu \mathrm{M}$ dNTP (Fermentas), $1.5 \mathrm{mM} \mathrm{MgCl}^{++}, 0.375$ unit Taq polymerase (Fermentas), 5 pmol of each primary pair (Table 1), and 50-100 ng template DNA were used in a single reaction. Each PCR reaction was prepared as $15 \mu \mathrm{L}$ in volume.
PCRs were performed at two steps using MJ Research PTC-200 Thermal Cycler. After a complete denaturation at $95^{\circ} \mathrm{C}$ for 2 minutes, step I consisted of denaturation at $94^{\circ} \mathrm{C}$ for 45 seconds for five cycles, annealing at $59^{\circ} \mathrm{C}$ for 45 seconds, and elongation at $72^{\circ} \mathrm{C}$ for 30 seconds. Step II consisted of a total of 30 cycles, each including $94^{\circ} \mathrm{C}$ for 30 seconds, $60^{\circ} \mathrm{C}$ for 30 seconds, and $72^{\circ} \mathrm{C}$ for 20 seconds. Finally, a complete adenylation was enabled by keeping the samples at $72^{\circ} \mathrm{C}$ for 10 minutes.

The resulting PCR products were loaded onto a Beckman Coulter CEQ-8000 Genetic Analysis System and allele genotypes were identified eluting by capillary electrophoresis.

2.3. Statistical Analysis. Number of alleles ( $\mathrm{Na}$ ), expected (He) and observed (Ho) heterozygosity levels, F-statistics, factorial correspondence analysis (FCA), phylogenetic trees (NJT), and structure analysis were determined using GenAlEx6 [18], Population 1.0 [19], TreeWiev [20], GENETIX 4.0 [21], and Structure v2.2 [22] package programs.

\section{Results}

Among general population parameters, number of observed alleles (Na; Table 2), expected ( $\mathrm{He}$ ) and observed (Ho) heterozygosity levels (Table 3), NJT (Figure 1), FCA (Figure 2), and structure (Figure 3 ) were summarized. 
TABLE 3: Observed (Ho) and expected (He) heterozygosities at eleven microsatellite loci.

\begin{tabular}{|c|c|c|c|c|c|c|c|c|c|}
\hline \multirow[b]{2}{*}{ Loci } & \multirow[b]{2}{*}{$\mathrm{Ho} / \mathrm{He}$} & \multicolumn{8}{|c|}{ Population } \\
\hline & & $\begin{array}{c}\text { Kilis } \\
(n=32)\end{array}$ & $\begin{array}{l}\text { Yayladag } \\
(n=32)\end{array}$ & $\begin{array}{c}\text { Shami } \\
(n=32)\end{array}$ & $\begin{array}{c}\text { Honamli } \\
(n=32)\end{array}$ & $\begin{array}{c}\text { Saanen } \\
(n=28)\end{array}$ & $\begin{array}{c}\text { Hair } \\
(n=32)\end{array}$ & $\begin{array}{c}\text { Angora } \\
(n=43)\end{array}$ & $\begin{array}{c}\text { Alpine } \\
(n=13)\end{array}$ \\
\hline \multirow{2}{*}{ SPS113 } & Ho & 0.600 & 0.692 & 0.781 & 0.767 & 0.893 & 0.862 & 0.707 & 0.923 \\
\hline & $\mathrm{He}$ & 0.729 & 0.661 & 0.709 & 0.756 & 0.821 & 0.807 & 0.801 & 0.769 \\
\hline \multirow{2}{*}{ McM527 } & Ho & 0.700 & 0.704 & 0.594 & 0.700 & 0.704 & 0.759 & 0.675 & 0.692 \\
\hline & $\mathrm{He}$ & 0.761 & 0.604 & 0.733 & 0.704 & 0.645 & 0.754 & 0.690 & 0.710 \\
\hline \multirow{2}{*}{ CSRD247 } & Ho & 0.833 & 0.926 & 0.844 & 0.967 & 0.607 & 0.767 & 0.805 & 0.846 \\
\hline & $\mathrm{He}$ & 0.819 & 0.791 & 0.797 & 0.845 & 0.612 & 0.812 & 0.842 & 0.793 \\
\hline \multirow{2}{*}{ BM6444 } & Ho & 0.875 & 0.875 & 0.938 & 0.903 & 0.704 & 0.774 & 0.805 & 0.833 \\
\hline & $\mathrm{He}$ & 0.863 & 0.863 & 0.917 & 0.877 & 0.867 & 0.851 & 0.903 & 0.858 \\
\hline \multirow{2}{*}{ ILSTS087 } & Ho & 0.469 & 0.656 & 0.656 & 0.813 & 0.704 & 0.781 & 0.575 & 0.727 \\
\hline & $\mathrm{He}$ & 0.484 & 0.635 & 0.667 & 0.756 & 0.769 & 0.748 & 0.525 & 0.702 \\
\hline \multirow{2}{*}{ TCRVB6 } & Ho & 0.875 & 0.969 & 0.781 & 0.844 & 0.630 & 0.871 & 0.744 & 0.692 \\
\hline & $\mathrm{He}$ & 0.896 & 0.854 & 0.853 & 0.819 & 0.755 & 0.869 & 0.858 & 0.669 \\
\hline \multirow{2}{*}{ DRBP1 } & Ho & 0.281 & 0.406 & 0.387 & 0.188 & 0.464 & 0.219 & 0.550 & 0.222 \\
\hline & $\mathrm{He}$ & 0.738 & 0.669 & 0.687 & 0.446 & 0.576 & 0.487 & 0.747 & 0.451 \\
\hline \multirow{2}{*}{ MAF70 } & Ho & 0.677 & 0.688 & 0.806 & 0.742 & 0.643 & 0.813 & 0.732 & 0.769 \\
\hline & $\mathrm{He}$ & 0.779 & 0.763 & 0.836 & 0.797 & 0.738 & 0.796 & 0.784 & 0.757 \\
\hline \multirow{2}{*}{ ETH10 } & Но & 0.531 & 0.281 & 0.484 & 0.688 & 0.321 & 0.625 & 0.800 & 0.750 \\
\hline & $\mathrm{He}$ & 0.703 & 0.579 & 0.673 & 0.558 & 0.427 & 0.608 & 0.704 & 0.681 \\
\hline \multirow{2}{*}{ P19 (DYA) } & Но & 0.625 & 0.452 & 0.833 & 0.719 & 0.643 & 0.656 & 0.860 & 0.700 \\
\hline & $\mathrm{He}$ & 0.767 & 0.789 & 0.821 & 0.821 & 0.841 & 0.815 & 0.855 & 0.810 \\
\hline \multirow{2}{*}{ INRA023 } & Ho & 0.688 & 0.935 & 0.900 & 0.625 & 0.519 & 0.548 & 0.667 & 0.500 \\
\hline & $\mathrm{He}$ & 0.691 & 0.817 & 0.835 & 0.488 & 0.445 & 0.445 & 0.733 & 0.705 \\
\hline \multirow{2}{*}{ Mean } & Ho & 0.650 & 0.689 & 0.728 & 0.723 & 0.621 & 0.698 & 0.720 & 0.696 \\
\hline & $\mathrm{He}$ & 0.748 & 0.729 & 0.775 & 0.715 & 0.681 & 0.727 & 0.767 & 0.719 \\
\hline
\end{tabular}

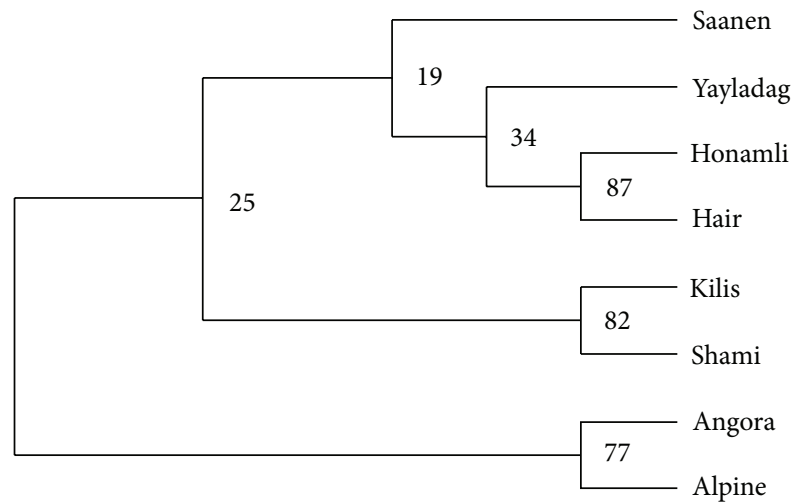

FIGURE 1: Neighbor-joining tree indicating phylogenetic relationship between Turkish native goat breeds.

In the present study, a total of 160 different alleles were observed and the mean $\mathrm{Na}$ was found to be 14.55. The highest number of alleles (33 alleles) was observed in BM6444, whereas the lowest number of alleles (10 alleles) was observed in McM527 and ILSTS087 markers.

It was determined that the mean Ho level changed between 0.188 and 0.969 , whereas the mean He levels were observed between 0.427 and 0.917 (Table 3). Mean Ho and

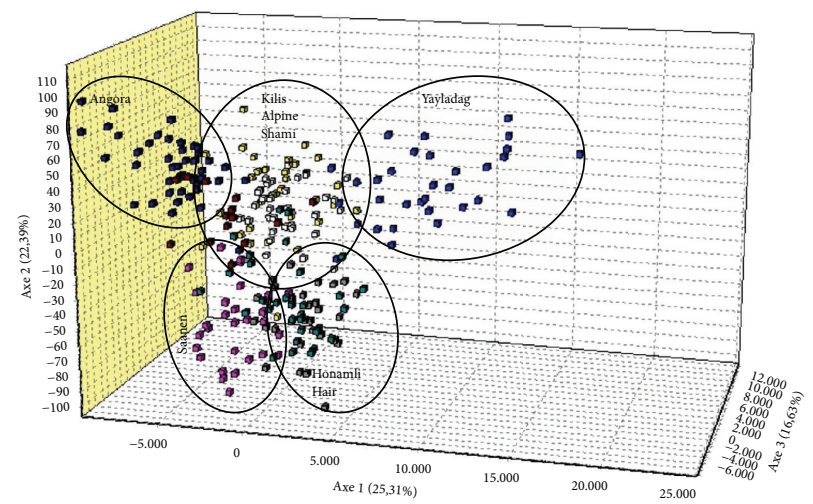

Figure 2: The FCA plot of the populations.

He levels were similar in general and heterozygosity among populations was generally high.

In order to evaluate genetic variation between populations, Wright's $F$-statistics was used and $F_{\mathrm{ST}}$ values were between 0.005 and 0.125 (Table 4). Total $F_{\mathrm{ST}}$ value (0.075) calculated for all loci was found to be statistically important $(P<0.001)$.

When the tree showing phylogenetic relation was analyzed by neighbor-joining tree (NJT) method using $D_{A}$ 
TABLE 4: $F_{\mathrm{ST}}$ (lower diagonal) and $D_{A}$ (upper diagonal) values.

\begin{tabular}{|c|c|c|c|c|c|c|c|c|}
\hline & Kilis & Yayladag & Shami & Honamli & Saanen & Hair & Angora & Alpine \\
\hline Kilis & - & 0.252 & 0.131 & 0.191 & 0.225 & 0.176 & 0.176 & 0.221 \\
\hline Yayladag & $0.075^{* * *}$ & - & 0.254 & 0.215 & 0.321 & 0.207 & 0.285 & 0.293 \\
\hline Shami & $0.038^{* * *}$ & $0.072^{* * *}$ & - & 0.178 & 0.226 & 0.170 & 0.207 & 0.248 \\
\hline Honamli & $0.079^{* * *}$ & $0.080^{* * *}$ & $0.072^{* * *}$ & - & 0.194 & 0.071 & 0.247 & 0.269 \\
\hline Saanen & $0.110^{* * *}$ & $0.125^{* * *}$ & $0.104^{* * *}$ & $0.070^{* * *}$ & - & 0.174 & 0.262 & 0.262 \\
\hline Hair & $0.074^{* * *}$ & $0.078^{* * *}$ & $0.075^{* * *}$ & $0.005 \mathrm{~ns}$ & $0.062^{* * *}$ & - & 0.210 & 0.254 \\
\hline Angora & $0.049^{* * *}$ & $0.086^{* * *}$ & $0.057^{* * *}$ & $0.090^{* * *}$ & $0.108^{* * *}$ & $0.078^{* * *}$ & - & 0.198 \\
\hline Alpine & $0.054^{* * *}$ & $0.099^{* * *}$ & $0.071^{* * *}$ & $0.094^{* * *}$ & $0.090^{* * *}$ & $0.084^{* * *}$ & $0.046^{* * *}$ & - \\
\hline
\end{tabular}

( ${ }^{* * *} P<0.001$, ns: nonsignificant.)

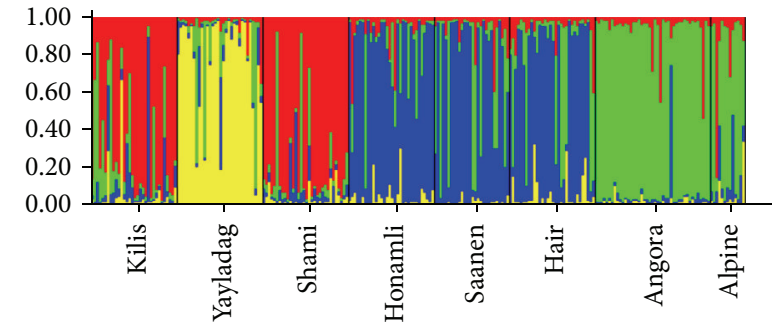

FIGURE 3: Structure analysis.

genetic distance values of Nei, it was observed that the populations have been clustered in three main groups (Figure 1). Among these, Saanen, Yayladag, Honamli, and Hair were clustered together. The other groups including Kilis and Shami, Angora and Alpine populations were separated in different radiation.

Factorial correspondence analysis (FCA) was performed to determine the genetic relation between the individuals used in the study and each individual was placed on 3dimensional plane according to their genotypes (Figure 2). Individuals of Ankara, Saanen, and Yayladag populations usually formed their own groups. However, it was observed that the subjects of other goat populations were grouped close to each other but did not much differ.

Structure test was performed to identify which population or populations the study subjects belong to as well as group them (Figure 3 ). $K=4$ analyses revealed that all populations differed from each other and that Angora, Alpin, and Yayladag populations in particular are more pure breed compared to the others.

\section{Discussion}

The mean number of alleles observed in the study (14.55) and the number of alleles at each loci (10-33) were close to the findings of the other study, which was also conducted in Turkish goat populations using 20 microsatellite markers [13]. Three loci (CSRD247, MAF70, and INRA023) were the same between these studies and numbers of alleles were similar, although the highest number of alleles was reported between 7 and 24 in other goat populations [8, 23-28].
The mean Ho and He values (0.690 and 0.733, resp.) found in the present study were higher than those found in goat genetic characterization studies conducted in different countries using different numbers of microsatellites [29-31]. Moreover $\mathrm{Na}, \mathrm{Ho}$, and $\mathrm{He}$ values reported in almost all Asian and African countries [12] were lower than those obtained in the present study. These results indicate higher genetic diversity among Turkish goat populations. The reason for this might be the facts that Turkey is located on migration route and is close to the initial domestication centers [32, 33].

In a genetic study conducted using 13 microsatellites, 6 indigenous Iranian goat populations were separated into two main groups based on phylogenetic tree and FCA analysis [34]. Mitochondrial DNA analysis of local Chinese goat populations [35] revealed that they formed 4 haplogroups and the results were consistent with archeological and genetic studies. In addition, genetic characterization studies, which were performed using 30 microsatellites [36] reported that the populations, which were raised in northwest and southwest as two sets in accordance with their geographical regions, heaped up within themselves.

In the present study, it was observed that Honamli and Hair goat populations grouped together on the NJT. This suggests that there is high relationship between Honamli and Hair goats and that gene flow is possible as they are raised in close geographical regions. In addition, FCA graph demonstrated that Honamli and Hair goats grouped together in line with these findings. Assignment test was performed to identify the populations using genotypic data and it was observed that animals were generally (93\%) assigned in their own populations. It was determined that 8 different populations, which were used also in the structure test, were discriminated from each other and that Angora, Alpine, and Yayladag were more pure breed compared to other populations. Results of assignment and structure analyses revealed that microsatellites used in the study are very useful in discriminating the populations.

There is no data or information in Turkey about Yayladag goat population used in the present study. However, previous research $[37,38]$ indicated that Hatay goat was obtained by hybridization of Hair $\times$ Kilis. However, Yayladag does not seem to be genetically so close to Hair or Kilis. Although they appear in the same group on NJT, Yayladag is grouped as a different population in the FCA and structure analyses. 
It was thought that suitable geographical structure of Hatay province for goat breeding and presence of many populations may be effective in the formation of a new genotype.

In conclusion, microsatellites are quite reliable markers to be used in the studies to investigate genetic variety and genetic structures of populations and to determine whether the subjects belong to the claimed populations. In addition, there is need for further studies using different markers system to obtain additional data on Yayladag goat.

\section{Disclosure}

The study has been presented as an abstract at the XXXI Conference of the International Society for Animal Genetics.

\section{Competing Interests}

The authors declare that they have no competing interests.

\section{Acknowledgments}

This research was supported by Selcuk University BAP (Project no. 05401104).

\section{References}

[1] TUIK, "Hayvansal Üretim İstatistikleri," December 2015, http://www.tuik.gov.tr/PreIstatistikTablo.do?istab_id=682.

[2] M. Keskin, Ö. Gökdal, O. Atay, and A. Konyalı, “Türkiye’de yetiştirilen keçi ırkları,” Tarım Türk, vol. 35, no. 7, pp. 71-74, 2012.

[3] TAGEM, "Türkiye Evcil Hayvan Genetik Kaynakları Tanıtım Katalogu," Ankara, Turkey, 2009, http://www.tarim.gov.tr/TAGEM/ Belgeler/yayin/Katalog\%20T\%C3\%BCrk\%C3\%A7e.pdf.

[4] Ö. K. Ağaoğlu and O. Ertuğrul, "Assessment of genetic diversity, genetic relationship and bottleneck using microsatellites in some native Turkish goat breeds," Small Ruminant Research, vol. 105, no. 1-3, pp. 53-60, 2012.

[5] C. Elmacı and S. Asal, "Ankara keçilerinde transferin (betaglobulin) polimorfizmi," Turkish Journal of Veterinary and Animal Sciences, vol. 22, no. 4, pp. 321-323, 1998.

[6] O. Ertuğrul and B. Akyüz, "Halk elinde yetiştirilen Ankara keçilerinde (Capra hircus) bazı kan protein polimorfizmi," Ankara Üniversitesi Veteriner Fakültesi Dergisi, vol. 47, no. 1, pp. 23-29, 2000.

[7] V. Altunok, M. Nizamlıŏlu, and Z. Bulut, "Ankara keçilerinin genetik yapılarının nişasta jel elektroforezi yöntemiyle araştırılmas1," Veteriner Bilimleri Dergisi, vol. 21, no. 2, pp. 67-72, 2007.

[8] M.-H. Li, S.-H. Zhao, C. Bian et al., "Genetic relationships among twelve Chinese indigenous goat populations based on microsatellite analysis," Genetics Selection Evolution, vol. 34, no. 6, pp. 729-744, 2002.

[9] R. Behl, N. Sheoran, J. Behl, R. K. Vijh, and M. S. Tantia, "Analysis of 22 heterologous microsatellite markers for genetic variability in Indian goats," Animal Biotechnology, vol. 14, no. 2, pp. 167-175, 2003.

[10] O. M. Jandurová, T. Kott, B. Kottová, and V. Czerneková, “Seven microsatellite markers useful for determining genetic variability in White and Brown Short-Haired goat breeds," Small Ruminant Research, vol. 52, no. 3, pp. 271-274, 2004.
[11] Y.-J. Zhang, Y.-Z. Zhao, Y.-Q. Liu, Y. Li, S.-H. Sun, and H.-X. Xing, "Genetic polymorphism of 4 microsatellites DNA in 3 goat populations and relationship with heterosis," Yi Chuan, vol. 26, no. 5, pp. 631-636, 2004.

[12] F. M. M. T. Marikar and M. M. Musthafa, "Usefulness of short sequence repeat markers in goat genetic diversity studies on the Asian and African continents," Turkish Journal of Veterinary and Animal Sciences, vol. 38, no. 6, pp. 606-611, 2014.

[13] Ö. K. Aĝaoĝlu and O. Ertuĝrul, "Assessment of genetic diversity, genetic relationship and bottleneck using microsatellites in some native Turkish goat breeds," Small Ruminant Research, vol. 105, no. 1-3, pp. 53-60, 2012.

[14] Y. Özşensoy, E. Kurar, Z. Bulut, and M. Nizamlioğlu, "Y chromosome analysis of native Turkish cattle breeds by microsatellite markers," Turkish Journal of Biology, vol. 38, no. 3, pp. 388395, 2014.

[15] Y. Özşensoy, E. Kurar, M. Dogan et al., “Türkiye'de bulunan bazı yerli sığır urklarının STR markörler ile genetik karakterizasyonu," Biyoloji Bilimleri Araştırma Dergisi, vol. 3, no. 1, pp. 163$171,2010$.

[16] S. Aksu, D. Aktopraklıgil, E. Koban et al., "Gen kaynaklarının ve biyoçeșitliliğin korunması kapsamında yerli at ırklarının genetik karakterizasyonu," Biyoloji Bilimleri Araştırma Dergisi, vol. 3, no. 1, pp. 129-138, 2010.

[17] J. Sambrook, E. F. Fritsch, and T. Maniatis, Molecular Clonning: A Laboratory Manual, vol. 2, Cold-Spring Harbor, New York, NY, USA, 2nd edition, 1989.

[18] R. Peakall and P. E. Smouse, "GENALEX 6: genetic analysis in excel. Population genetic software for teaching and research," Molecular Ecology Notes, vol. 6, no. 1, pp. 288-295, 2006.

[19] D. B. Goldstein and D. D. Pollock, "Launching microsatellites: a review of mutation processes and methods of phylogenetic inference," Journal of Heredity, vol. 88, no. 5, pp. 335-342, 1997.

[20] R. D. M. Page, "TreeView: an application to display phylogenetic trees on personal computers," Computer Applications in the Biosciences, vol. 12, no. 4, pp. 357-358, 1996.

[21] K. Belkhir, P. Borsa, L. Chikhi, J. Goudet, and F. Bonhomme, Genetix 4.00 Windows ${ }^{\mathrm{TM}}$ Software Population Genetics, Laboratoire Genome, Populations, Interactions, University of Montpellier, Montpellier, France, 1996-2000.

[22] D. Falush, M. Stephens, and J. K. Pritchard, "Inference of population structure using multilocus genotype data: dominant markers and null alleles," Molecular Ecology Notes, vol. 7, no. 4, pp. 574-578, 2007.

[23] G. Luikart, M.-P. Biju-Duval, O. Ertugrul, Y. Zagdsuren, C. Maudet, and P. Taberlet, "Power of 22 microsatellite markers in fluorescent multiplexes for parentage testing in goats (Capra hircus)," Animal Genetics, vol. 30, no. 6, pp. 431-438, 1999.

[24] A. M. de Araújo, S. E. F. Guimarães, T. M. M. Machado et al., "Genetic diversity between herds of Alpine and Saanen dairy goats and the naturalized Brazilian Moxotó breed," Genetics and Molecular Biology, vol. 29, no. 1, pp. 67-74, 2006.

[25] S. Bolormaa, A. Ruvinsky, S. Walkden-Brown, and J. van der Werf, "DNA-based parentage verification in two Australian goat herds," Small Ruminant Research, vol. 80, no. 1-3, pp. 95-100, 2008.

[26] M. Siwek and E. F. Knol, "Parental reconstruction in rural goat population with microsatellite markers," Italian Journal of Animal Science, vol. 9, no. 3, article e50, 2010.

[27] C. Visser, E. V. Marle Köster, and H. Friedrich, "Parentage verification of South African Angora goats, using microsatellite 
markers," South African Journal of Animal Sciences, vol. 41, no. 3, pp. 250-255, 2011.

[28] R. S. Aljumaah, M. M. Musthafa, M. A. Al-Shaikh, O. M. Badri, and M. F. Hussein, "Genetic diversity of Ardi goat based on microsatellite analysis," African Journal of Biotechnology, vol. 11, no. 100, pp. 16539-16545, 2012.

[29] A. M. Martínez, M. P. Carrera, J. M. Acosta et al., "Genetic characterisation of the Blanca Andaluza goat based on microsatellite markers," South African Journal of Animal Sciences, vol. 34, no. 5, supplement 1, pp. 17-19, 2004.

[30] C. Visser, C. A. Hefer, E. van Marle-Köster, and A. Kotze, "Genetic variation of three commercial and three indigenous goat populations in South Africa," South African Journal of Animal Sciences, vol. 34, no. 5, supplement 1, pp. 24-27, 2004.

[31] B. Fan, J.-L. Han, S.-L. Chen et al., "Individual-breed assignments in caprine populations using microsatellite DNA analysis," Small Ruminant Research, vol. 75, no. 2-3, pp. 154-161, 2008.

[32] G. Luikart, L. Gielly, L. Excoffier, J.-D. Vigne, J. Bouvet, and P. Taberlet, "Multiple maternal origins and weak phylogeographic structure in domestic goats," Proceedings of the National Academy of Sciences of the United States of America, vol. 98, no. 10, pp. 5927-5932, 2001.

[33] M. W. Bruford, D. G. Bradley, and G. Luikart, "DNA markers reveal the complexity of livestock domestication," Nature Reviews Genetics, vol. 4, no. 11, pp. 900-910, 2003.

[34] B. Mahmoudi, B. Panahi, S. A. Mohammadi, M. Daliri, and M. S. Babayev, "Microsatellite based phylogeny and bottleneck studies of Iranian indigenous goat populations," Animal Biotechnology, vol. 25, no. 3, pp. 210-222, 2014.

[35] Y. Zhao, R. Zhao, Z. Zhao, H. Xu, E. Zhao, and J. Zhang, "Genetic diversity and molecular phylogeography of Chinese domestic goats by large-scale mitochondrial DNA analysis," Molecular Biology Reports, vol. 41, no. 6, pp. 3695-3704, 2014.

[36] C. Wei, J. Lu, L. Xu et al., "Genetic structure of Chinese indigenous goats and the special geographical structure in the Southwest China as a geographic barrier driving the fragmentation of a large population," PLoS ONE, vol. 9, no. 4, Article ID e94435, 2014.

[37] M. Keskin and O. Biçer, "Hatay bölgesinde yetiştirilen keçilerin bazı morfolojik ve fizyolojik özellikleri," Journal of Agricultural Faculty MKÜ, vol. 2, no. 1, pp. 73-86, 1997.

[38] O. Biçer, M. Keskin, S. Kaya, and S. Gül, "Comparison of some lactation characteristics of Hatay goat with Taurus dairy goat $\mathrm{X}$ Hatay goat crossbreeds," in Animal Production and Natural Resources Utilisation in the Mediterranean Mountain Areas, A. Georgoudis, A. Rosati, and C. Mosconi, Eds., pp. 287-291, Wageningen Academic Publishers, Wageningen, Netherlands, 2005. 

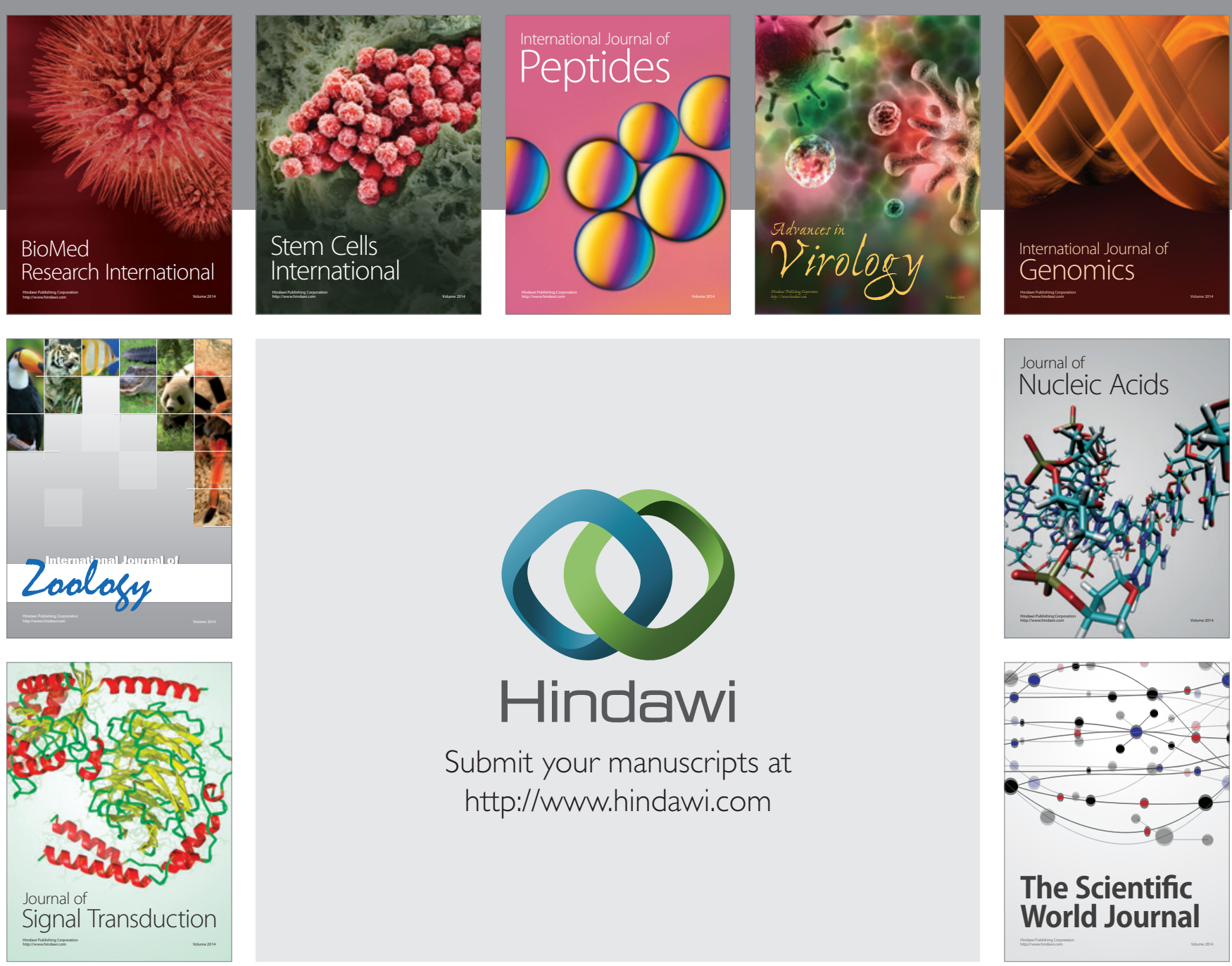

Submit your manuscripts at

http://www.hindawi.com
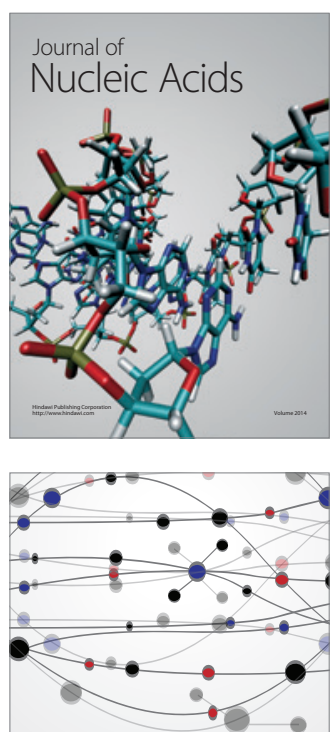

The Scientific World Journal
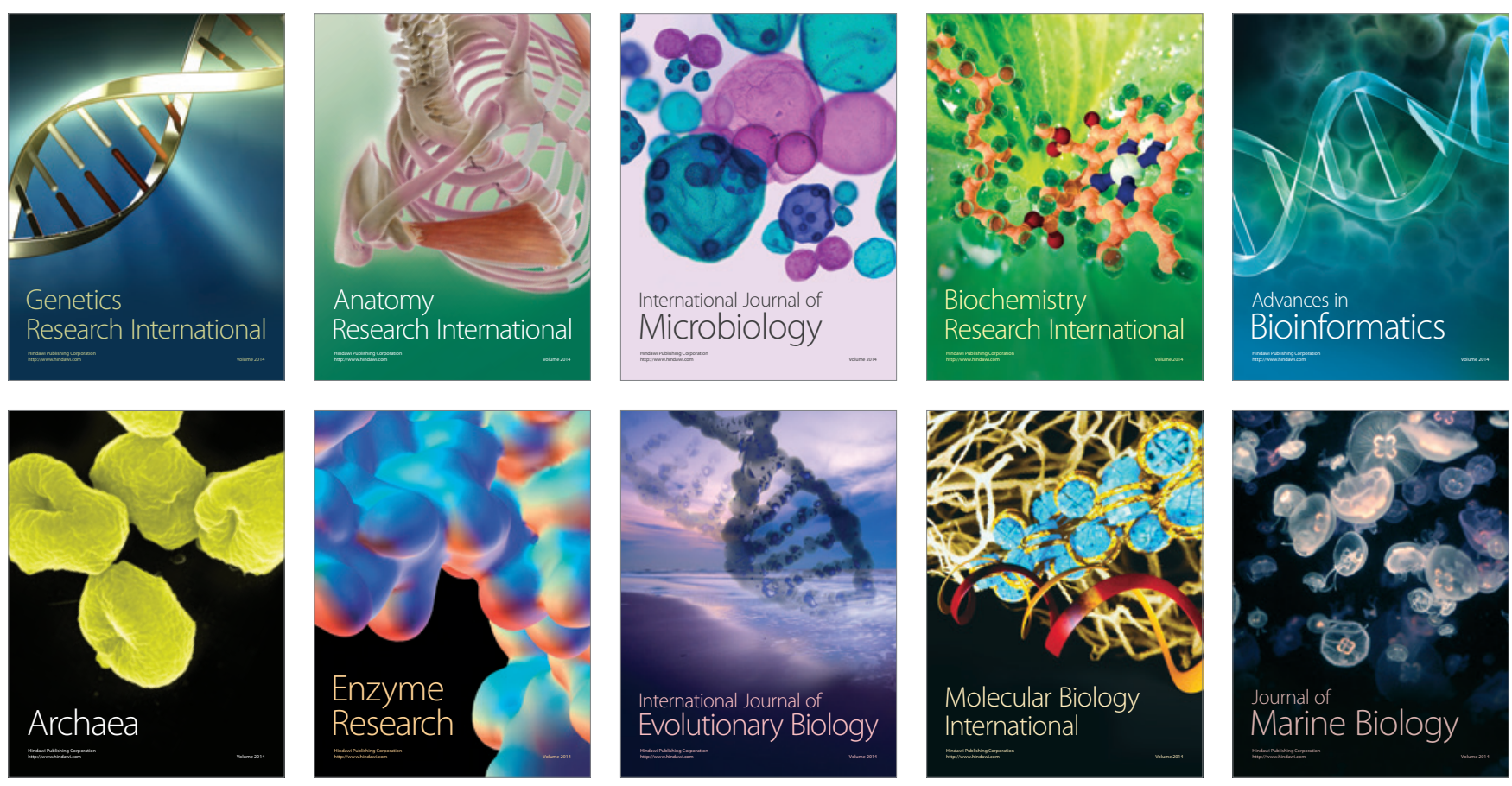